\title{
Dictyoglomus thermophilum gen. nov., sp. nov., a Chemoorganotrophic, Anaerobic, Thermophilic Bacterium
}

\author{
TAKASHI SAIKI, ${ }^{*}$ YASUHIKO KOBAYASHI, KIYOTAKA KAWAGOE, AND TERUHIKO BEPPU \\ Department of Agricultural Chemistry, The University of Tokyo, Yayoi 1-1-1, Bunkyo-ku, Tokyo 113, Japan
}

\begin{abstract}
We describe a new caldoactive bacterium, Dictyoglomus thermophilum, which was isolated from a slightly alkaline hot spring. This organism is a nonsporeforming, nonmotile, obligately anaerobic rod-shaped bacterium that stains gram negative and occurs singly, in pairs, in filaments, in bundles, and as spherical bodies. The cell surface structure is of the complex gram-negative type. Large spherical bodies are formed by associations of separate rods in numbers ranging from a few to perhaps as many as 100; these spherical bodies are surrounded by common outer wall membrane. The temperature range for growth is between 50 and $80^{\circ} \mathrm{C}$, with optimum growth at $78^{\circ} \mathrm{C}$; the pH range for growth is between 5.9 and 8.3. The doubling time at $73^{\circ} \mathrm{C}$ and pH 7.2 is about $2.5 \mathrm{~h}$. Growth is inhibited by streptomycin, tetracycline, neomycin, chloramphenicol, vancomycin, tunicamycin, and sodium dodecyl sulfate. The deoxyribonucleic acid base composition is 29 mol\% guanosine plus cytosine. The type strain is strain ATCC 35947.
\end{abstract}

Bacteria that grow at temperatures over $70^{\circ} \mathrm{C}$ are called caldoactive or extremely thermophilic $(10,18)$. It has been pointed out that volcanic environments such as hot springs may be more conducive for the growth of anaerobes than for the growth of aerobes because of the low solubility of $0_{2}$ at high temperatures, the presence of $\mathrm{H}_{2} \mathrm{~S}$, and the high organic content associated with decomposing biomass (20). Extremely thermophilic, anaerobic chemoorganotrophs, including Thermoanaerobium brockii (20), Thermoanaerobacter ethanolicus (19), and Thermobacteroides acetoethylicus (3), have been isolated from hot springs at Yellowstone National Park and from other volcanic environments during the past several years $(6,17,21-23)$. We examined hot springs in Japan with the hope of isolating thermophilic anaerobes which may be potentially useful for industrial purposes. One anaerobic isolate is described in this paper. This organism is an extremely thermophilic, nonsporulating, chemoorganotrophic, rod-shaped bacterium which forms large spherical bodies consisting of a few to perhaps 100 separate cells. The properties of this strain do not fit those of any previously described genus.

\section{MATERIALS AND METHODS}

Chemicals. All chemicals were reagent grade. Tetracycline and streptomycin sulfate were obtained from Takeda Chemical Industries Ltd., Osaka, Japan. Actinomycin D, Dcycloserine, ampicillin, and vancomycin were obtained from Sigma Chemical Co., St. Louis, Mo, penicillin G was obtained from Meiji Confectionary Co. Ltd., Kawasaki, Japan, neomycin was obtained from Boehringer Mannheim, Mannheim, Federal Republic of Germany, and chloramphenicol was obtained from Sankyo Co. Ltd., Tokyo, Japan. Tunicamycin was a gift from Akira Takatsuki, University of Tokyo, Tokyo, Japan. Lysozyme $(6 \times$ crystallized) was purchased from Seikagaku Kogyo Co. Ltd., Tokyo, Japan.

\footnotetext{
* Corresponding author.

$\dagger$ Present address: Alcohol Production Head Office, New Energy Development Organization, Toranomon 3-5-1, Minato-ku, Tokyo 105 , Japan.
}

Polypeptone, yeast extract, and agar powder were obtained from Takeda Chemical Industries Ltd., Daigoeiyo Chemical Co. Ltd., Osaka, Japan, and Kokusan Chemical Works, Ltd., Tokyo, Japan, respectively. Quetol 812 was provided by Nissin EM Co. Ltd., Tokyo, Japan.

Medium and cultivation conditions. The anaerobic techniques of Hungate (8) were used throughout this study. The anaerobic medium contained (per liter of distilled water) 1.5 $\mathrm{g}$ of $\mathrm{KH}_{2} \mathrm{PO}_{4}, 4.2 \mathrm{~g}$ of $\mathrm{Na}_{2} \mathrm{HPO}_{4} \cdot 12 \mathrm{H}_{2} \mathrm{O}, 0.5 \mathrm{~g}$ of $\mathrm{NH}_{4} \mathrm{Cl}$, $0.38 \mathrm{~g}$ of $\mathrm{MgCl}_{2} \cdot 6 \mathrm{H}_{2} \mathrm{O}, 0.05 \mathrm{~g}$ of $\mathrm{CaCl}_{2}, 0.039 \mathrm{~g}$ of $\mathrm{Fe}\left(\mathrm{NH}_{4}\right)_{2}\left(\mathrm{SO}_{4}\right)_{2} \cdot 6 \mathrm{H}_{2} \mathrm{O}, 1.0 \mathrm{~g}$ of $\mathrm{Na}_{2} \mathrm{CO}_{3}, 2.9 \mathrm{mg}$ of $\mathrm{CoCl}_{2}$. $6 \mathrm{H}_{2} \mathrm{O}, 2.4 \mathrm{mg}$ of $\mathrm{NaMoO}_{4} \cdot 2 \mathrm{H}_{2} \mathrm{O}, 0.17 \mathrm{mg}$ of $\mathrm{Na}_{2} \mathrm{SeO}_{3}, 2.0$ $\mathrm{mg}$ of $\mathrm{MnCl}_{2} \cdot 4 \mathrm{H}_{2} \mathrm{O}, 2.8 \mathrm{mg}$ of $\mathrm{ZnSO}_{4}, 2.0 \mathrm{mg}$ of resazurin, $20 \mu \mathrm{g}$ of biotin, $20 \mu \mathrm{g}$ of folic acid, $100 \mu \mathrm{g}$ of pyridoxin hydrochloride, $5 \mu \mathrm{g}$ of riboflavin, $5 \mu \mathrm{g}$ of thiamine, $50 \mu \mathrm{g}$ of nicotinic acid, $50 \mu \mathrm{g}$ of pantothenic acid, $1 \mu \mathrm{g}$ of vitamin $\mathrm{B}_{12}$, $50 \mu \mathrm{g}$ of thioctic acid, $50 \mu \mathrm{g}$ of $p$-aminobenzoic acid, $2 \mathrm{~g}$ of yeast extract, $2 \mathrm{~g}$ of polypeptone, $5 \mathrm{~g}$ of soluble starch, and $1.0 \mathrm{~g}$ of cysteine hydrochloride. The gas phase in all cultures was nitrogen $\left(1\right.$ atmosphere $\left.\left[1.1 \times 10^{2} \mathrm{kPa}\right]\right)$. The $\mathrm{pH}$ of the medium after autoclaving was about 7.2. Vitamins, growth inhibitors (except $\mathrm{NaCl}$ and sodium dodecyl sulfate), and antibiotics were sterilized separately by filtration. Cultures were incubated at $73^{\circ} \mathrm{C}$ unless otherwise stated.

Determination of fermentation products. A glass gas chromatography column $(1.0 \mathrm{~m}$ by $3 \mathrm{~mm}$ ) containing $60 / 80$-mesh activated charcoal (Shimadzu Corp., Kyoto, Japan) was used for analysis of $\mathrm{H}_{2}, \mathrm{CO}_{2}$, and $\mathrm{N}_{2}$. The column temperature was $75^{\circ} \mathrm{C}$, the injection temperature was $120^{\circ} \mathrm{C}$, and the detector temperature was $100^{\circ} \mathrm{C}$. The carrier gas was helium (flow rate, $30 \mathrm{ml} / \mathrm{min}$ ). A thermoconductivity detector was used. Ethanol and acetic acid were analyzed with a glass column ( $1 \mathrm{~m}$ by $3 \mathrm{~mm}$ ) packed with 80/100-mesh Gaskuropak 54 (Gasukuro Kogyo, Inc., Tokyo, Japan). The column temperature was $165^{\circ} \mathrm{C}$, and the flame ionization detector temperature was $135^{\circ} \mathrm{C}$; helium was the carrier gas (flow rate, $55 \mathrm{ml} / \mathrm{min}$ ). The same column and detector were used for analysis of volatile acids other than acetic acid; the column temperature was $180^{\circ} \mathrm{C}$, the injection temperature was $220^{\circ} \mathrm{C}$, and the detector temperature was $220^{\circ} \mathrm{C}$. Volatile and nonvolatile acids also were analyzed with a JASCO Tri 

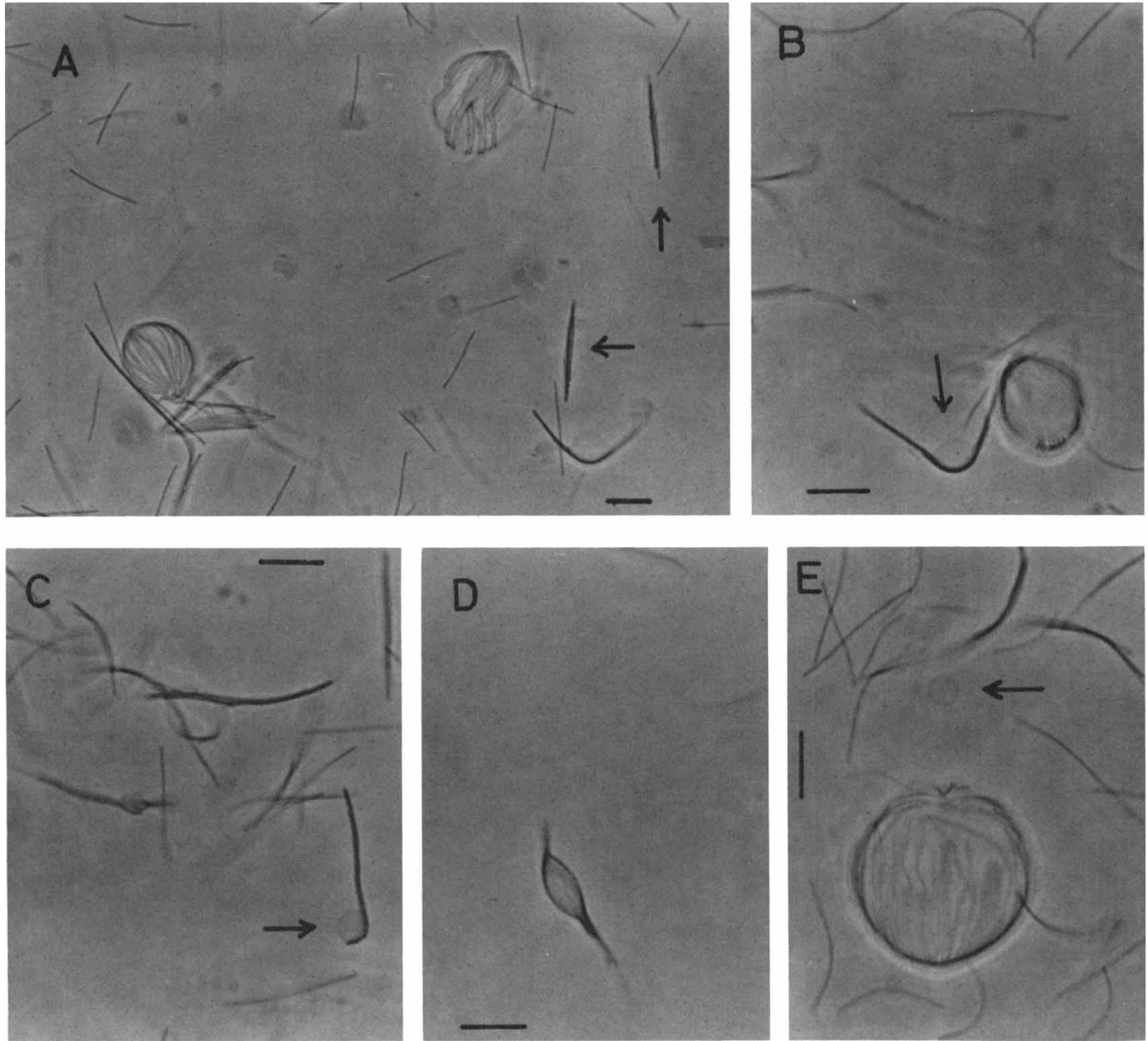

FIG. 1. Phase-contrast photomicrographs of D. thermophilum H-6-12 ${ }^{\mathrm{T}}$. (A) Cells in singles, pairs, bundles (arrows), and large spherical bodies. (B through D) Immature spherical bodies. (E) Small spherical body with no cells inside (arrow). Cultures were grown at $73^{\circ} \mathrm{C}$ for 29 $\mathrm{h}(\mathrm{A})$ or in a minijar fermentor for $17 \mathrm{~h}(\mathrm{~B}$ and $\mathrm{C}), 8 \mathrm{~h}(\mathrm{D})$, and $20 \mathrm{~h}(\mathrm{E})$. Bars $=10 \mu \mathrm{m}$.

Rotor high-performance liquid chromatograph equipped with a model 100 ultraviolet detector (Japan Spectroscopic Co. Ltd., Tokyo, Japan) and a model RI SE-11 refractive index detector (Showa Denko K.K., Tokyo, Japan). The column used contained type C-811 Shodex Ionpak $\left(-\mathrm{SO}_{4}\right.$ type) cation exchange resin (Showa Denko). Lactate was determined enzymatically $[\mathrm{L}(+)$-lactic acid reagent set 826-UV; Sigma]. Glucose was determined enzymatically with the Glucose B-Test (Wako Code 271-31401; Wako Pure Chemical Industries, Ltd., Osaka, Japan). Total sugar was determined with the anthrone-sulfuric acid reagent (13).

Growth measurement. Increases in cellular protein were determined as follows: cells from $0.2 \mathrm{ml}$ of culture broth were collected by centrifugation at $5,000 \times g$ for $15 \mathrm{~min}$ ); the protein was precipitated in cold $5 \%$ trichloric acid, solubilized by heating at $98^{\circ} \mathrm{C}$ for $5 \mathrm{~min}$ in $1 \mathrm{M} \mathrm{NaOH}$, and measured by the method of Lowry et al. (11), using bovine serum albumin as the protein standard.

DNA base composition. Isolation of deoxyribonucleic acid (DNA), measurement of its melting temperature, and calculation of its guanine-plus-cytosine $(\mathrm{G}+\mathrm{C})$ content were performed as described by Saiki et al. (16).

Biochemical tests. Biochemical properties were studied by the methods of Holdeman et al. (7).
Electron microscopy. Cells grown for 2 days at $73^{\circ} \mathrm{C}$ were collected by low-speed centrifugation and fixed in $0.01 \mathrm{M}$ cacodylate buffer $(\mathrm{pH} 7.0)$ containing $1 \%$ glutaraldehyde and $0.15 \mathrm{M} \mathrm{NaCl}$ for $1 \mathrm{~h}$. The cells were then dehydrated gradually by washing with increasing concentrations of ethanol and dried by the critical-point method (1). Finally, the samples were dried on grids which were coated with gold-palladium and examined with a model S-430 scanning electron microscope (Hitachi Seisakusho Co. Ltd., Hitachi, Japan). Cells also were fixed by the method of Ryter and Kellenberger (15), with some modifications. Glutaraldehyde (final concentration, $2.5 \%$ ) was added to $100 \mathrm{ml}$ of a $24-\mathrm{h}$ culture of strain $\mathrm{H}-6-12^{\mathrm{T}}(\mathrm{T}=$ type strain). Cells were collected by centrifugation at $500 \times g$ for $10 \mathrm{~min}$, suspended in $5 \mathrm{ml}$ of Kellenberger buffer (Veronal acetate buffer containing $0.1 \mathrm{M} \mathrm{CaCl}_{2}$ at $\mathrm{pH} \mathrm{6.1)}$, and centrifuged at $60 \times g$ for $8 \mathrm{~min}$ to remove black mineral precipitates. The cells were resuspended in the same buffer containing $2.5 \%$ glutaraldehyde and left at room temperature for $1 \mathrm{~h}$. Then the cells were washed with $8 \mathrm{ml}$ of buffer, suspended in $1 \mathrm{ml}$ of buffer containing $1 \%$ osmic acid and $0.1 \mathrm{ml}$ of tryptone medium, and incubated overnight at room temperature. The cells were washed with $8 \mathrm{ml}$ of buffer, suspended in $1 \mathrm{ml}$ of a $2 \%$ agar solution $\left(65^{\circ} \mathrm{C}\right)$, and immediately centrifuged at $500 \times g$ 

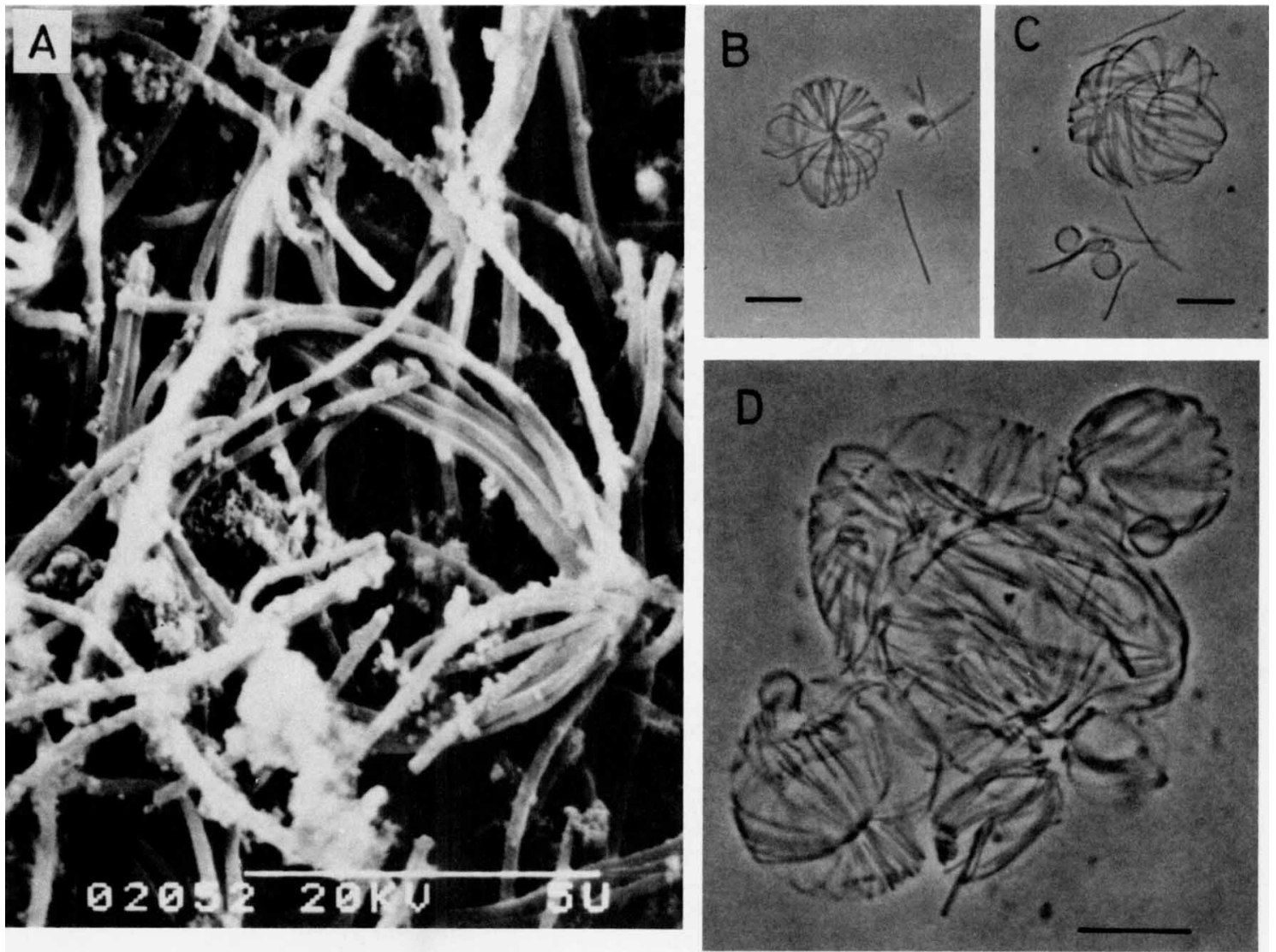

FIG. 2. Large spherical bodies. (A) Scanning electron micrograph. (B and C) Phase-contrast photomicrographs. Bars $=10 \mu \mathrm{m}$. (D) Aggregate of several large spherical bodies. Phase-contrast photomicrograph. Bar $=10 \mu \mathrm{m}$.

for $10 \mathrm{~min}$. The solidified agar was cut into 1- to $2-\mathrm{mm}$ cubes. The cubes were placed in $1 \mathrm{ml}$ of buffered $0.5 \%$ uranyl acetate for $2 \mathrm{~h}$. The agar blocks were dehydrated by a graded series of water-ethanol mixtures, followed by acetone. They were infiltrated with an acetone-Quetol 812 mixture and embedded in Quetol 812 by incubation at $37^{\circ} \mathrm{C}$ overnight, at $45^{\circ} \mathrm{C}$ for 1 day and finally at $60^{\circ} \mathrm{C}$ for 2 days. Thin sections were cut with model MT-2 ultramicrotome (Ivan Sorvall, Inc., Norwalk, Conn.) and stained with a $3 \%$ aqueous uranyl acetate solution, followed by lead citrate, as described by Reynolds (14). Electron microscopy was done with a model JEM JEOL $200 \mathrm{CX}$ electron microscope.

Enrichment and isolation. Water samples containing mud and sediments were collected in 1-liter polyethylene bottles. The tightly capped bottles were kept in a cold room. These samples $(20 \mathrm{ml}$ each) were inoculated into $300-\mathrm{ml} \mathrm{Er}$ lenmeyer flasks containing $100 \mathrm{ml}$ of medium and incubated anaerobically at 73 to $75^{\circ} \mathrm{C}$. The cultures in which visible turbidity developed in 3 to 5 days were transferred to anaerobic culture tubes. After 2 to 3 days of incubation, 10 -fold serial dilutions were made and inoculated into medium containing $2.5 \%$ molten agar. The agar medium in roll tubes was incubated at 60 to $63^{\circ} \mathrm{C}$ in a $30^{\circ}$ slanted position. The final stock cultures were obtained by selecting wellisolated single colonies. Roll tube culture was repeated several times. Strain H-6-12 ${ }^{\mathrm{T}}$ was isolated from one of the six water samples collected from Tsuetate Hot Spring (Kumamoto Prefecture, Japan) in February 1982. The temperature and $\mathrm{pH}$ of the water were $82^{\circ} \mathrm{C}$ and 8.7 , respec- tively. Stock cultures of strain $\mathrm{H}-6-12^{\mathrm{T}}$ were stored under nitrogen at $-20^{\circ} \mathrm{C}$ in $50 \%$ glycerol for at least 6 months and by lyophilization.

\section{RESULTS AND DISCUSSION}

The cells of strain $\mathrm{H}-6-12^{\mathrm{T}}$ were gram-negative, nonsporeforming, nonflagellated, obligately anaerobic, long rods that associated to form large spherical bodies. An outer wall membrane was present. The fermentation products were acetate, lactate, and $\mathrm{CO}_{2}$. The $\mathrm{G}+\mathrm{C}$ content of the DNA was $29 \mathrm{~mol} \%$.

These characteristics differ significantly from those of previously described obligately thermophilic, asporogeneous, fermentative anaerobes as described below.

Thermoanaerobium brockii is a gram-positive, nonsporeforming, nonmotile, rod-shaped organism that produces lactate, ethanol, acetate, $\mathrm{H}_{2}$, and $\mathrm{CO}_{2}$ as fermentation products. Its DNA base composition is 30 to $31 \mathrm{~mol} \% \mathrm{G}+\mathrm{C}$ (20).

Thermoanaerobacter ethanolicus is gram variable (gram positive in the very early logarithmic growth phase) and has peritrichous flagella. It produces ethanol as the main fermentation product and lactate, acetate, and $\mathrm{CO}_{2}$ as minor products. Its DNA base composition is 37 to $38 \mathrm{~mol} \% \mathrm{G}+\mathrm{C}$ (19).

Thermobacteroides acetoethylicus is a gram-negative, peritrichously flagellated, nonsporeforming, rod-shaped organism that produces ethanol, acetate, $\mathrm{H}_{2}$, and $\mathrm{CO}_{2}$. Its cell 
wall architecture is not typical of gram-positive or gramnegative bacteria. An outer wall membrane, which is common to most gram-negative bacteria, has not been observed. Its DNA base composition is $31 \mathrm{~mol} \% \mathrm{G}+\mathrm{C}(3)$.

Strain H-6-12 ${ }^{\mathrm{T}}$ cannot be identified as a member of any of the genera described above or any other genus described in Bergey's Manual of Determinative Bacteriology and Bergey's Manual of Systematic Bacteriology $(5,9)$. Therefore, we propose to place strain $\mathrm{H}-6-12^{\mathrm{T}}$ in a new genus and species, Dictyoglomus thermophilum gen. nov., sp. nov., which are described below.

Dictyoglomus gen. nov. Dictyoglomus (Dic. ty. o. glo' mus. Gr. n. dictyon net; glomus L. n. ball; L. n. Dictyoglomus net ball) cells are gram-negative rods with a gram-negative type of cell surface structure, often forming bundles and large spherical bodies. The bundles and large spherical bodies consist of two to several cells and several dozen cells, respectively, and are surrounded by a common outer wall membrane. Nonmotile and nonsporulating. Obligately anaerobic and carbohydrate fermenting. The $\mathrm{G}+\mathrm{C}$ content of the type species is $29 \mathrm{~mol} \%$. The type species is Dictyoglomus thermophilum.

Dictyoglomus thermophilum sp. nov. D. thermophilum (ther. mo. phil' um; Gr. n. thermus heat; L. adj. philum loving; L. n. thermophilum heat loving) cells are rods that are 0.4 to $0.6 \mu \mathrm{m}$ wide by 5 to $20 \mu \mathrm{m}$ long and occur singly, in pairs, in filaments, and in bundles. Several to several dozen cells frequently form large spherical bodies up to 50 to $100 \mu \mathrm{m}$ in diameter. Gram-negative, nonsporeforming, and nonmotile.

Anaerobic; does not grow in an aerobic atmosphere or in a medium in which the color has become light pink due to the oxidation of resazurin by a trace amount of air.

In the late log phase of growth 30 to $50 \%$ of the cells are in large bodies (Fig. 1 and 2). Cell aggregates in linear arrays consist of two to several cells and share an outer wall membrane. There seem to be various intermediate forms during growth from single cells to large spherical bodies. The cells may grow and duplicate inside the outer wall membrane. Any excess outer wall membrane produced may be pinched off to form small empty spherical bodies.

Electron microscopic observations indicate that the various types of spherical structures are composed of outer wall membrane. Electron micrographs of ultrathin sections show that the cell surface structure is of the complex gram-negative type (Fig. 3). Flagella are not present. Neither complex membranous structures such as mesosomes nor invaginations of the plasma membrane are observed. The outer layer appears to be a definite membranous structure, no portion of which is connected with the underlying innermost layer. Electron-dense materials are observed between the outer and inner membranes.

Large spherical bodies are formed by association of separate filamentous cells, which are surrounded by a membranous structure (Fig. 4d). This membranous structure is composed of the outer wall membranes which have partially peeled away from the cell surfaces. Figures $4 \mathrm{~A}$ through $\mathrm{C}$ show examples in which two, three and several cells share an outer wall membrane. These forms may be observed as bundles or immature spherical bodies under a light microscope (Fig. 1). There is evidence from elecron micrograph sections (Fig. 5) that the large spherical bodies are actually three-dimensional structures of associated cells surrounded by an outer wall membrane.

The cell division profile of strain $\mathrm{H}-6-12^{\mathrm{T}}$ resembles that of gram-negative bacteria, such as Escherichia coli or Thermus

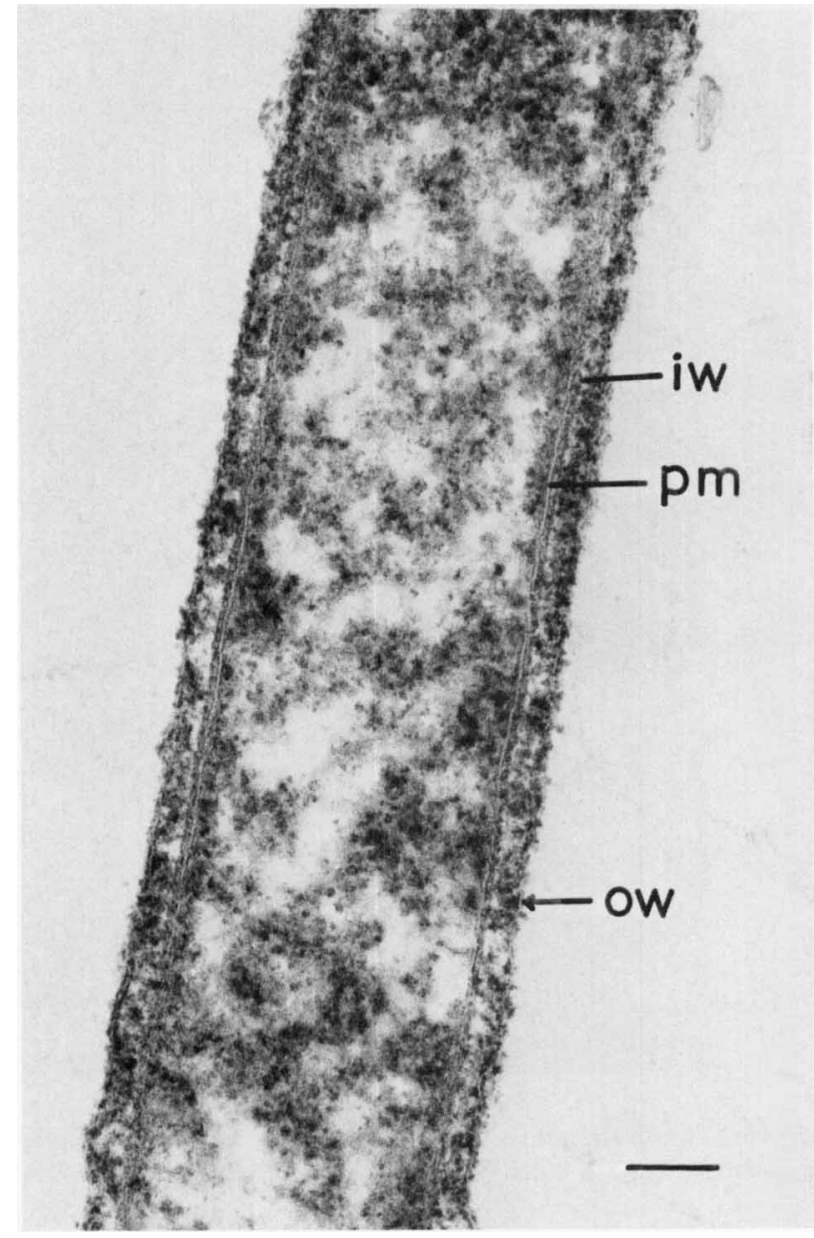

FIG. 3. Longitudinal section of a cell. The cell surface structure is composed of a plasma membrane (pm), an inner wall (iw) and an outer wall (ow). Bar $=0.1 \mu \mathrm{m}$.

aquaticus (4). Deep narrow invaginations of the cell envelope are formed (Fig. 6). The cell envelope is tripartite (plasma membrane, thin middle layer, and an outer wall membrane). The bundles and large spherical bodies consist of associated cells surrounded by an outer wall membrane.

Colonies are uniformly round and nonpigmented and grow to a diameter of 2 to $4 \mathrm{~mm}$ in 3 to 5 days at $60^{\circ} \mathrm{C}$.

The optimum temperature range for growth is 73 to $78^{\circ} \mathrm{C}$, the maximum temperature is $80^{\circ} \mathrm{C}$, and the minimum temperature is $51^{\circ} \mathrm{C}$. The doubling time at $77^{\circ} \mathrm{C}$ in anaerobic culture tubes is about $3.6 \mathrm{~h}$. The doubling times at $73^{\circ} \mathrm{C}$ in anaerobic culture tubes and minijar fermentors are about 4.3 and $2.5 \mathrm{~h}$ (Fig. 7 and 8), respectively.

The optimum $\mathrm{pH}$ for growth is about 7; no growth is produced above $\mathrm{pH} 8.9$ or below $\mathrm{pH} 5.4$.

The organism does not grow in media lacking fermentable carbohydrate. The carbohydrates used as energy sources include amygdalin, arabinose, cellobiose, fructose, fucose, galactose, glucose, lactose, maltose, mannose, melezitose, melibiose, pectin, raffinose, ribose, sucrose, trehalose, xylose, and insoluble starch of potato. Cellulose, $\mathrm{m}$ erythritol, glycerol, L-inositol, mannitol, pyruvate, rhamnose, sorbitol, xylitol, and insoluble starch from corn and wheat are not fermented. 

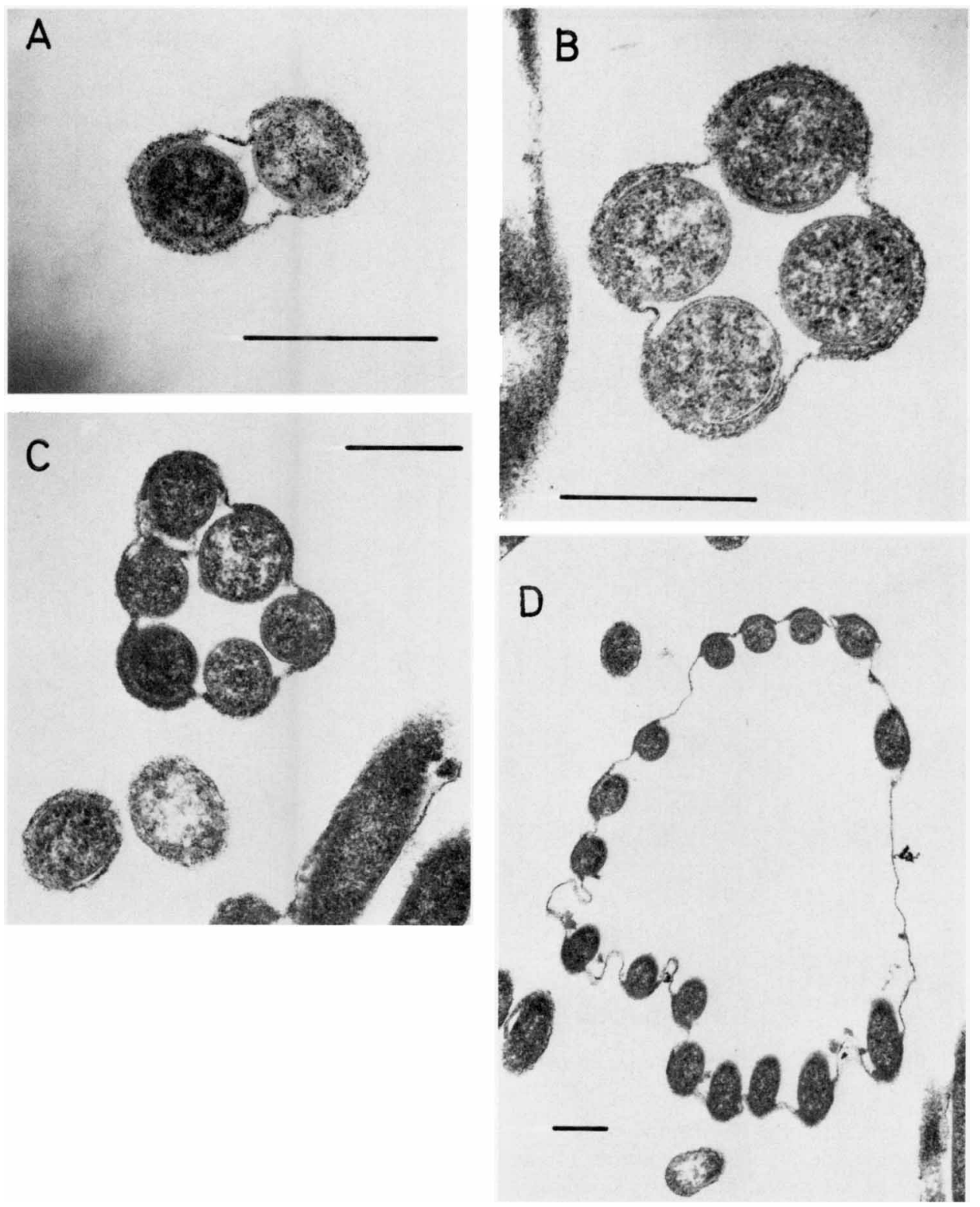

FIG. 4. Cross-sections of 2 (A), 4 (B), 6 (C), and 16 (D) rod-shaped cells which are connected by their outer wall membranes to form a bundle or spherical body. Bars $=0.5 \mu \mathrm{m}$.

Strain H-6-12 ${ }^{\mathrm{T}}$ ferments $0.5 \%$ soluble starch to produce 16 $\mathrm{mM}$ acetate, $3 \mathrm{mM}$ lactate, about $12 \mathrm{mM} \mathrm{CO}_{2}$, and trace amounts of $\mathrm{H}_{2}$.

A very heat stable $\alpha$-amylase is produced.

The methyl red test, indole production, and nitrate reduction are negative. The Voges-Proskauer test is positive. Catalase activity is not detected.

Growth is inhibited by $10 \mu \mathrm{g}$ of streptomycin per $\mathrm{ml}, 10 \mu \mathrm{g}$ of tetracycline per $\mathrm{ml}, 100 \mu \mathrm{g}$ of chloramphenicol per $\mathrm{ml}, 10$ $\mu \mathrm{g}$ of neomycin per $\mathrm{ml}, 100 \mu \mathrm{g}$ of vancomycin per $\mathrm{ml}, 100 \mu \mathrm{g}$ of actinomycin D per $\mathrm{ml}, 10 \mu \mathrm{g}$ of tunicamycin per $\mathrm{ml}, 2 \%$ sodium chloride, and $100 \mu \mathrm{g}$ of sodium dodecyl sulfate per $\mathrm{ml}$.

Cells are resistant to lysozyme and lysozyme plus ethylenediaminetetraacetate. Incubation of cells in $50 \mathrm{mM}$ tris (hydroxymethyl) aminomethane hydrochloride buffer (pH 7.6) containing $78 \mu \mathrm{g}$ of lysozyme per $\mathrm{ml}$ and $1 \mathrm{mM}$ ethylenediaminetetraacetate for $20 \mathrm{~min}$ at $37^{\circ} \mathrm{C}$ causes no decrease in absorbance at $550 \mathrm{~nm}$ of a cell suspension. However, light microscope observations reveal the appearance of partial extrusions like protoplast structures from some long cells. After incubation the cells are lysed by the addition of $1 \%$ sodium dodecyl sulfate, whereas the addition of the same concentration of sodium dodecyl sulfate does not lyse untreated cells. The large spherical bodies are rapidly decomposed to separate filamentous cells by the addition of $0.1 \%$ sodium dodecyl sulfate, whereupon each cell become thinner.

Isolated from slightly alkaline hot springs (Tsuetate Hot Spring) in Kumamoto Prefecture, Japan.

The DNA base composition is $29 \mathrm{~mol} \% \mathrm{G}+\mathrm{C}$.

HoloType strain: Dictyoglomus thermophilum H-6-12 (= ATCC 35947).

Brock and Edwards reported the production of similar 

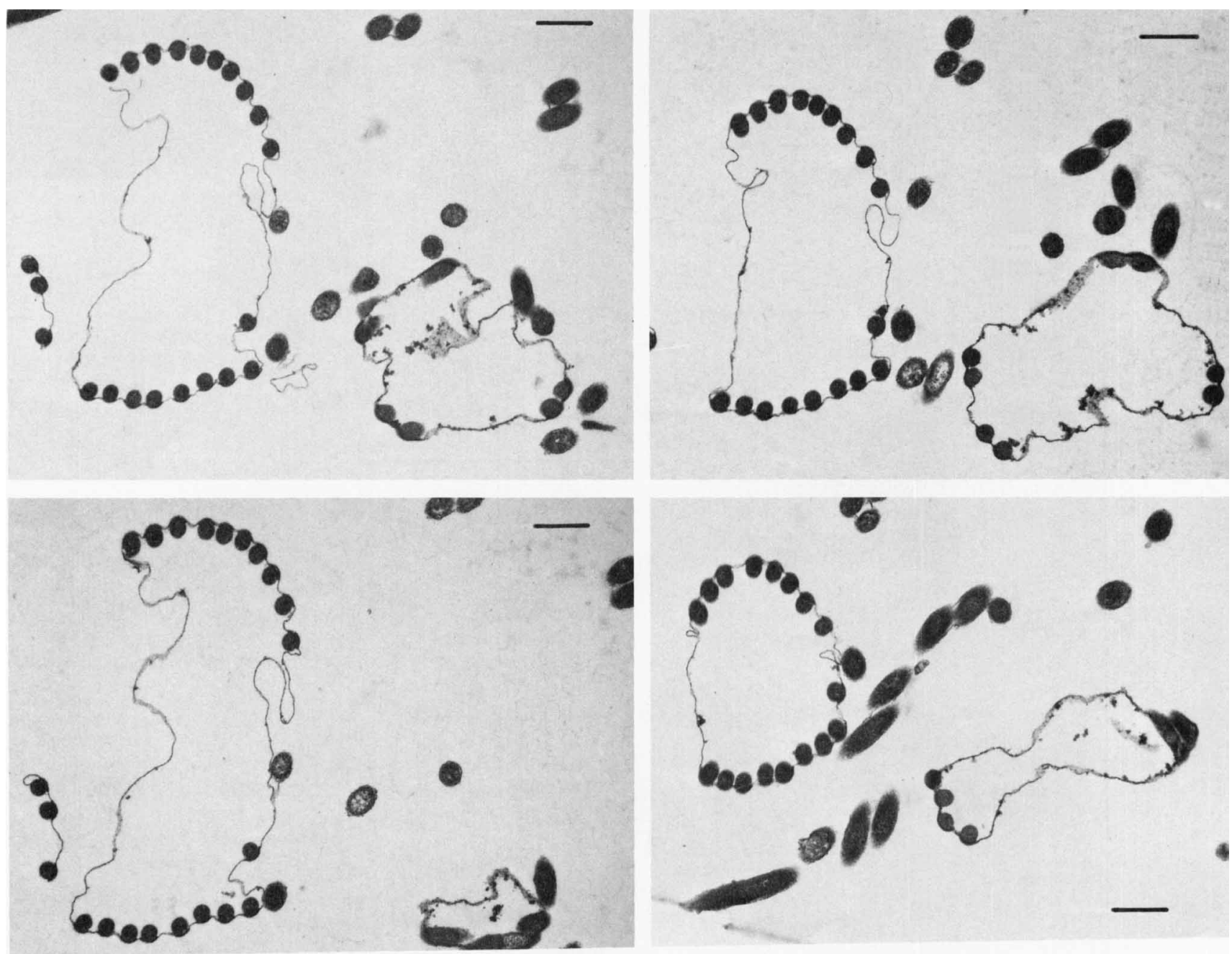

FIG. 5. Cross-sections picked from serial sections of large spherical bodies. Bars $=1 \mu \mathrm{m}$.

large spherical bodies, which they called rotund bodies, by an aerobic extreme thermophile, Thermus aquaticus (4). In Thermus aquaticus, Escherichia coli (2), and Thiobacillus thiooxidans (12) portions of the outer wall membrane are connected to the underlying innermost layer. In $D$. thermophilum connections between the outer wall layer and the underlying innermost layer cannot be seen. This apparent lack of the connection may allow easy peeling of the
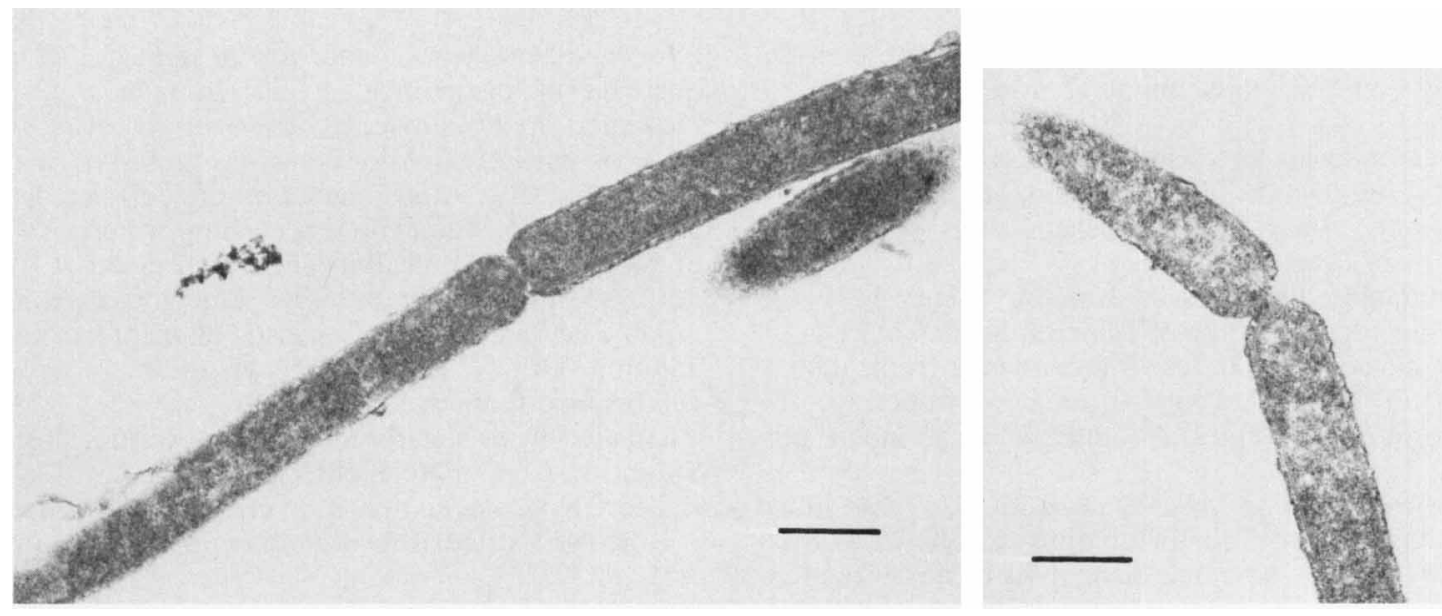

FIG. 6. Phases of cell division. Bars $=0.5 \mu \mathrm{m}$. 


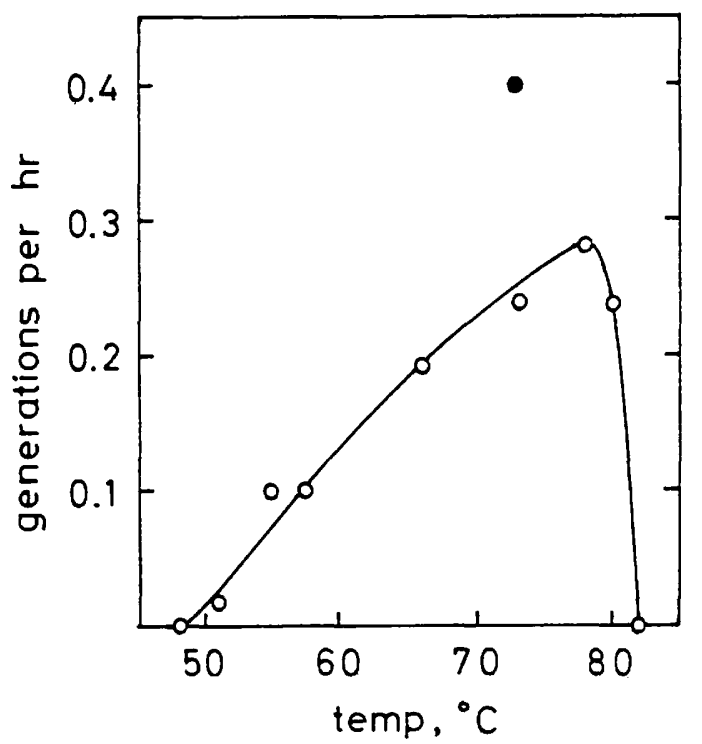

FIG. 7. Growth rate of $D$. thermophilum $\mathrm{H}-6-12^{\mathrm{T}}$ at different temperatures. The organism was grown in culture tubes $(O)$ and in a minijar fermentor (⿶).

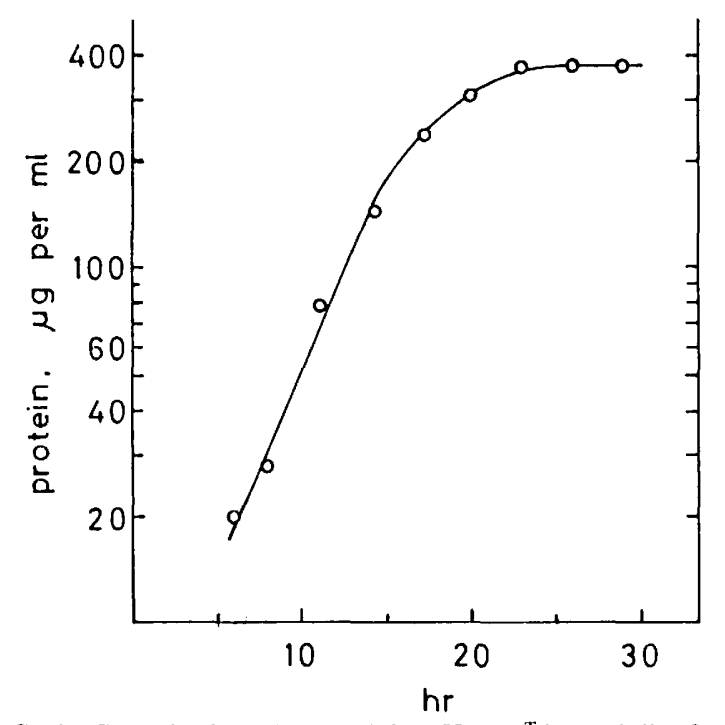

FIG. 8. Growth of D. thermophilum $\mathrm{H}-6-12^{\mathrm{T}}$ in a minijar fermentor at $73^{\circ} \mathrm{C}$.

outer wall membrane from cells to form the "empty bodies" observed in most cultures.

\section{ACKNOWLEDGMENT}

We thank Aiko Hirata, Institute of Applied Microbiology, University of Tokyo, Tokyo, Japan, for her help and advice in electron microscopy.

\section{LITERATURE CITED}

1. Amako, K., and M. Koike. 1982. Electron microscopy techniques in microbiology. Japan Scientific Societies Press, Tokyo. (In Japanese.)

2. Bayer, M. E. 1967. Response of cell walls of Escherichia coli to a sudden reduction of the environmental osmic pressure. J.
Bacteriol. 93:1104-1112.

3. Ben-Bassat, A., and J. G. Zeikus. 1981. Thermobacteroides acetoethylicus gen. nov. and sp. nov., a new chemoorganotrophic, anaerobic, thermophilic bacterium. Arch. Microbiol. 128:365-370.

4. Brock, T. D., and M. R. Edwards. 1970. Fine structure of Thermus aquaticus, an extreme thermophile. J. Bacteriol. 104:509-517.

5. Buchanan, R. E., and N. E. Gibbons (ed.). 1974. Bergey's manual of determinative bacteriology, 8th ed. The Williams \& Wilkins Co., Baltimore.

6. Fischer, F., W. Zillig, K. O. Stetter, and G. Schreiber. 1983. Chemolithoautotrophic metabolism of anearobic extremely thermophilic archaebacteria. Nature (London) 301:511-513.

7. Holdeman, L. V., E. P. Cato, and W. E. C. Moore (ed.). 1977. Anaerobe laboratory manual, 4th ed. Anaerobe Laboratory, Virginia Polytechnic Institute and State University, Blacksburg.

8. Hungate, R. E. 1969. A roll tube method for cultivation of strict anaerobes, p. 117-132. In J. R. Norris and D. W. Ribbons (ed.), Methods in microbiology, vol. 3B. Academic Press, Inc., London.

9. Krieg, N. R. (ed.). 1984. Bergey's manual of systematic bacteriology, vol. 1. The Williams \& Wilkins Co., Baltimore.

10. Ljungdahl, L. G. 1980. Physiology of thermophilic bacteria. Adv. Microbiol. 19:149-243.

11. Lowry, O. H., N. J. Rosebrough, A. L. Farr, and R. J. Randall. 1951. Protein measurement with the Folin phenol reagent. J. Biol. Chem. 193:265-275.

12. Mahoney, R. P., and M. R. Edwards. 1966. Fine structure of Thiobacillus thiooxidans. J. Bacteriol. 92:487-495.

13. Morris, D. L. 1984. Quantitiative determination of carbohydrates with Dreywood's anthrone reagent. Science 107: $254-255$.

14. Reynolds, E. S. 1963 . The use of lead citrate at high $\mathrm{pH}$ as an electron-opaque stain in electron microscopy. J. Cell Biol. 17:208-212.

15. Ryter, A., and E. Kellenberger. 1958. Etude an microscope electronique de plasmas contendant de l'acid desoxyribonucleique. I. Les nucleoides des bacteries en croissance active. Z. Naturforsch. Teil B 13:597-605.

16. Saiki, T., R. Kimura, and K. Arima. 1972. Isolation and characterization of extremely thermophilic bacteria from hot springs. Agric. Biol. Chem. 36:2357-2366.

17. Stetter, K. O. 1982. Ultrathin mycelia-forming organisms from submarine volcanic areas having an optimum growth temperature of $105^{\circ} \mathrm{C}$ Nature (London) 300:258-260.

18. Tansey, M. R., and T. D. Brock. 1978. Microbial life at high temperatures: ecological aspects, p. 159-216. In D. J. Kushner (ed.), Microbial life in extreme environments. Academic Press, Inc., London.

19. Wiegel, J., and L. G. Ljungdahl. 1981. Thermoanaerobacter ethanolicus gen. nov., sp. nov., a new, extreme thermophilic, anaerobic bacterium. Arch. Microbiol. 128:343-348.

20. Zeikus, J. G., P. W. Hegge, and M. A. Anderson. 1979. Thermoanaerobium brockii gen. nov. and sp. nov., a new chemoorganotrophic caldoactive, anaerobic bacterium. Arch. Microbiol. 122:41-48.

21. Zillig, W., A. Gierl, G. Schreiber, S. Wunderl, D. Janekovic, K. O. Stetter, and H. P. Klenk. 1983. The archaebacterium Thermofilum pendens represents a novel genus of the thermophilic, anaerobic sulfur respiring Thermoproteales. Syst. Appl. Microbiol. 4:79-87.

22. Zillig, W., I. Holz, D. Janekovic, W. Schafer, and W. D. Reiter. 1983. The archaebacterium Thermococcus celer represents a novel genus within the thermophilic branch of the archaebacteria. Syst. Appl. Microbiol. 4:88-94.

23. Zillig, W., K. O. Stetter, W. Schafer, D. Janekovic, S. Wunderl, I. Holz, and P. Palm. 1981. Thermoproteales: a novel type of extremely thermoacidophilic anaerobic archaebacteria isolated from Icelandic solfataras. Zentralbl. Bakteriol. Parasitenkd. Infektionskr. Hyg. Abt. 1 Orig. Reihe C 25:205-227 